ДУБРОВИНА Ольга Юрьевна - кандидат политических наук, доцент Сибирского института международных отношений и регионоведения (630075, Россия, г. Новосибирск, ул. Народная, 14; olgadubrovina@mail.ru)

\title{
ПРИГРАНИЧНОЕ СОТРУДНИЧЕСТВО КАК ФОРМА МЕЖРЕГИОНАЛЬНОГО ВЗАИМОДЕЙСТВИЯ И РЕГИОНАЛИЗАЦИИ
}

Аннотация. В данной статье приграничное сотрудничество рассматривается как форма межрегионального взаимодействия и регионализации. Главное внимание уделено основным понятиям, специфическому потенциалу приграничья, особой роли приграничных территорий в развитии государств. Автор дает анализ феномена трансграничности, который неразрывно связан с изменяющимися функциями границы. В статье показано, что трансграничность возможна только при условии наличия проницаемости пространства.

В статье рассматривается правовая база, основные цели и задачи приграничного сотрудничества, а также наиболее важные геополитические факторы, оказывающие существенное влияние на приграничные отношения.

Ключевые слова: глобализация, регионализация, регионы государств, международные связи регионов государств, трансграничное сотрудничество, приграничное сотрудничество, трансграничность, граница, приграничная территория, приграничный район, пограничность

$\mathrm{T}$ рансформационные сдвиги, происходящие в современном мире под воздействием глобализации и регионализации, обусловливают необходимость осмысления роли приграничного сотрудничества. Приграничное сотрудничество является формой межрегионального взаимодействия и регионализации.

Говоря о приграничном сотрудничестве, сразу определимся, что речь идет о сотрудничестве регионов государств. В данном случае рассматривается регион, который находится ниже уровня государства, но выше уровня местного самоуправления, о так называемом субнациональном регионе государств [Дубровина 2012: 20].

Приграничное сотрудничество осуществляется в приграничном регионе. Некоторые авторы определяют приграничный регион как территорию, осуществляющую регулярное взаимодействие с приграничными территориями сопредельных государств на уровне экономических, культурных, правовых связей на принципах относительной взаимодополняемости потенциала и ресурсов с соблюдением взаимных интересов [Бильчак 2014]. Нам представляется, что данное определение не совсем верно. Ведь приграничный регион останется таковым независимо от того, осуществляет он регулярное взаимодействие с приграничными территориями сопредельных государств или нет. Автор считает, что приграничный регион - это территория государства, расположенная вдоль его границы.

Если руководствоваться Европейской рамочной конвенцией о приграничном сотрудничестве территориальных сообществ и властей, то кроме термина «приграничный регион» используется термин «приграничная территория». Это понятие, безусловно, уже, чем понятие «приграничный регион», поскольку приграничная территория может принадлежать муниципальным и другим административным единицам.

В общем смысле приграничные территории - это территории, непосредственно прилегающие к государственной границе, испытывающие на себе наибольшее влияние границы и соседней страны и обладающие особым, дополнительным потенциалом развития и международного сотрудничества, 
«специфическим потенциалом приграничья», складывающимся из следующих составляющих, или факторов: 1) географическое положение - близость к государственной границе; 2) специфическая инфраструктура приграничья; 3) возможность широкого использования ресурсов и потенциала приграничья соседней страны; 3) возможность развития различных форм международного сотрудничества [Трансграничный регион... 2010: 19-20].

Выделенные элементы потенциала приграничья позволяют определить рубежи, внешние границы приграничной территории. Последние будут выделять территорию с максимально высоким или существенным потенциалом приграничья, включая все его составляющие.

Глобальные и региональные трансформации выявили особую роль приграничных территорий в развитии государств. Это связано с тем, что границы в современном мире перестали рассматриваться как барьеры, что превратило пограничье в контактную зону, в которой активно идет взаимодействие народов и наций, их культур и экономик. В современную эпоху пограничность, удаленность от центра уже не характеризуется как культурная или экономическая отсталость, а скорее рассматривается как обладание дополнительными возможностями экономического и социокультурного развития. Роль, которую играют пограничья в современном государстве, обусловливает актуальность исследования специфики пограничных территорий, проблем функционирования границ и феномена трансграничности, который неразрывно связан с изменяющимися функциями границы.

Одной из существенных характеристик современной межгосударственной границы является проницаемость, позволяющая выделить непроницаемые, полупроницаемые и прозрачные границы. Подобная дифференцированность обусловлена тем, что современные границы далеко не в одинаковой степени проницаемы для разных потоков, видов и субъектов деятельности. В итоге система границ эволюционирует от единственных рубежных линий - к множеству, от линий - к зонам, от физических границ - к культурным, от непроницаемых барьеров - к пространствам взаимодействия [Кучинская 2011].

Трансграничность возможна только при условии наличия проницаемости пространства - возможности осуществления социально-экономических и межкультурных связей.

В настоящее время недостаточная разработанность и поляризованность взглядов на проблемы границ приграничных регионов заставляет исследователей обратиться к категории пограничного пространства. Под этим термином понимается социально-географическая зона вдоль границы или вокруг пункта в глубине территории страны, в пределах которой наблюдаются пограничные процессы и явления, связанные с интересами соседних стран и взаимодействием между их экономическими, культурными, правовыми и политическими системами [Трансграничный регион... 2010].

Сходную точку зрения высказывает А.Б. Вардомский. Понятие «пространство», характеризуемое свойствами многомерности и полиструктурности, совпадает с понятием «территория» и зачастую связывается им с понятием «регион», обладающим четкой иерархической структурой - от низовых территориально-административных образований до группы стран в рамках различных объединений. Л.Б. Вардомский отмечает, что «системно-структурное понимание пространства опирается на анализ наблюдаемых в нем различий, выделение отдельных структурных элементов в пространстве, исследование отдельных структурных элементов пространства, процессов развития того или иного пространства, включая его внутреннюю интеграцию и взаимодействие с другими выделяемыми пространствами» [Кучинская 2011]. 
Пограничное пространство характеризуется тремя величинами: протяженностью (длиной), шириной (глубиной) и насыщенностью (плотностью или интенсивностью пограничных процессов и явлений). Однако критерии определения двух первых величин в настоящее время недостаточно разработаны, а третий - интенсивность - является качественным показателем и понимается как «средняя линия между границами “частных”, “отраслевых” приграничных пространств - экономического, культурного, политического и других, появляющихся как следствие соответствующих взаимодействий» [Кучинская 2011].

Исследования показали, что необходимость быстро решать все вопросы приграничья, преимущества непосредственной близости субнациональных регионов, которые разделяют государственные границы, а также то, что любая общая проблема в приграничном пространстве приобретает транснациональное измерение, привело к формированию приграничного сотрудничества.

Во многих научных источниках встречаются различные подходы к понятию приграничного сотрудничества. Для объективного анализа рассмотрим, как это понятие трактуется в официальных документах.

Так, в Европейской рамочной конвенции о приграничном сотрудничестве территориальных сообществ и властей под приграничным сотрудничеством понимаются любые согласованные действия, направленные на укрепление и поощрение добрососедских отношений между территориальными сообществами или властями, находящимися под юрисдикцией двух или более договаривающихся сторон, а также заключение любых соглашений и договоренностей, необходимых для достижения этих целей ${ }^{1}$. Приграничное сотрудничество осуществляется в рамках полномочий территориальных сообществ или властей, определяемых внутренним правом каждой из сторон ${ }^{2}$.

Очень важно, что в Конвенции подтверждается незыблемый принцип суверенитета приграничных государств. В этом документе предусмотрено, что система межгосударственных соглашений нацелена прежде всего на четкое закрепление содержания, форм и границ, которые государства определяют для деятельности территориальных властей, а также на устранение правовых неопределенностей, которые могут создать проблемы, связанные с разным толкованием законодательства, судебных полномочий, и возможность подачи апелляции. Для устранения межгосударственных различий, культурных и языковых барьеров в Конвенции предусмотрены следующие правовые и экономические процедуры: официальное признание законности процедур приграничного сотрудничества и поощрение их использования местными властями; определение цели и условий вмешательства курирующих или контролирующих властей; обмен информацией между государствами; взаимосвязь, которая может быть установлена между формами приграничного сотрудничества и другими согласованными действиями в приграничных районах; изменение правовых норм и их толкований, препятствующих приграничному сотрудничеству 3 .

В федеральном законе «Об основах приграничного сотрудничества в Российской Федерации» под приграничным сотрудничеством понимается часть международных отношений Российской Федерации, международных и внешнеэкономических связей субъектов Российской Федерации и муниципальных образований, которая представляет собой согласованные действия субъектов приграничного сотрудничества Российской Федерации и субъектов пригра-

\footnotetext{
${ }^{1}$ Европейская рамочная конвенция о приграничном сотрудничестве территориальных сообществ и властей от 21.05.1980. Доступ: https://zakonbase.ru/content/part/335504

2 Там же.

3 Там же.
} 
ничного сотрудничества сопредельных государств, направленные на решение задач, определяемых международными договорами Российской Федерации и настоящим Федеральным законом ${ }^{1}$.

Учитывая данные документы, автор предлагает под приграничным сотрудничеством понимать согласованные действия сопредельных регионов государств, направленные на укрепление отношений между соседними регионами, находящимися под юрисдикцией разных государств [Дубровина, Плотникова 2016: 16].

Приграничное сотрудничество осуществляется на основе международных соглашений и охватывает те области, которые находятся в компетенции заинтересованных сообществ и властей. Основной целью приграничного сотрудничества является налаживание связей между приграничными территориями, поиск совместных решений схожих проблем.

Английский теоретик приграничной интеграции П. Уайлз отмечает, что приграничное сотрудничество может осуществляться только при условии ассимиляции экономик регионов разных государств. Ассимиляция предполагает идентичность хозяйственной структуры всего сообщества и равную обеспеченность факторами производства всех составных частей интегрируемого пространства, чего не может дать один лишь рыночный механизм [Wiles 1968: 6].

Д.И. Шаповалов и В.М. Кузьмина, изучая приграничное сотрудничество, большое внимание уделяют геополитическим факторам, оказывающим на него влияние. С их точки зрения приграничные территории - это государственные территории, которые прилегают к границе государства, выполняют важные приграничные функции и обладают характерными особенностями [Шаповалов, Кузьмина 2015].

Важнейшим фактором, определяющим специфику приграничья, является географическое положение страны (ландшафт, климат, растительность, выход к морям и океанам, полезные ископаемые), протяженность границ, величина территории, численность и состав населения, которое проживает в стране и в приграничном регионе. Безусловно, важнейший фактор геополитики, от которого зависят все остальные, - это территория государства. Итак, можно назвать несколько наиболее важных геополитических факторов, которые оказывают существенное влияние на приграничные отношения.

Во-первых, это расположение той или иной страны на карте мира. Географическое положение играет важнейшую роль в экономическом и политическом сотрудничестве государств. Соответствующее развитие и сотрудничество двух и более стран позволяет качественно развивать транспортную инфраструктуру, образовать торговую сеть между государствами и повысить товарооборот.

Во-вторых, это наличие определенной инфраструктуры на границах государств. Автомобильные, железнодорожные пути, международные пункты пропуска позволяют обеспечить гуманитарные, культурные, туристические связи.

Следующий фактор - это наличие значительных запасов природных ресурсов. Это могут быть запасы древесины, полезные ископаемые, производство электроэнергии, водные ресурсы, туризм. Природные ресурсы той или иной страны служат основой для торгово-экономического сотрудничества с другими государствами.

Далее, это сходные климатические условия. Сходство природных условий двух и более стран, их флоры и фауны позволяет совместными усилиями решать проблемы сохранения природного разнообразия. Этой проблеме в настоящее

\footnotetext{
1 Проект Федерального закона N 351626-5 «Об основах приграничного сотрудничества в Российской Федерации» (ред., внес. в ГД ФС РФ, текст по сост. на 31.03.2010). Доступ: http://www.consultant.ru/ cons/cgi/online.cgi?base $=\mathrm{PRJ} \& \mathrm{n}=76327 \&$ req $=\mathrm{doc} \# 008858743385739776$
} 
время уделяется достаточно большое внимание. Также природная близость позволяет странам находить такие проекты, реализация которых будет представлять интерес для обеих сторон.

Сходство в структурах промышленности также играет существенную роль в приграничном сотрудничестве.

K важному фактору можно также отнести общее культурное наследие [Шаповалов, Кузьмина 2015].

Таким образом, научные подходы еще раз подтверждают закономерное развитие региональных процессов, особенно в приграничных зонах, которые подтверждают общий взгляд ученых и вывод о том, что приграничное сотрудничество очень важно и имеет огромное значение. Эти взгляды не всегда совпадают, и спор ученых о приграничном сотрудничестве остается незаконченным. Но важный вывод заключается в том, что приграничное сотрудничество всегда может иметь позитивные результаты.

Изучая приграничное сотрудничество, важно определить условия, в которых оно осуществляется, выяснить, что способствует приграничному сотрудничеству, а что ему мешает.

К благоприятным условиям приграничного сотрудничества можно отнести следующие факторы: 1) отсутствие серьезных пограничных проблем с соседними государствами; 2) создание законодательной базы, касающейся приграничного сотрудничества государств и их регионов; 3) наличие взаимной заинтересованности сторон в развитии международных связей; 4) поддержание и поощрение народной дипломатии; 5) создание социальных и экономических советов или трансграничных объединений; 6) проведение форумов, конференций; 7) наличие внутригосударственных мер в виде федеральных программ по созданию производственной, социальной и сервисной инфраструктуры и специальных мер поддержки по развитию приграничных территорий и т.д.

К условиям, тормозящим развитие приграничного сотрудничества, можно отнести: 1) пограничные претензии государств друг к другу; 2) различия регионов в экономическом и культурно-историческом развитии; 3) межконфессиональные проблемы; 4) отсутствие единой институционализации структур управления приграничным сотрудничеством; 5) различия в системах разграничения полномочий и предметов ведения в приграничных субъектах и т.д.

Подводя итог, можно сделать следующие выводы: приграничное сотрудничество как один из путей (видов) трансграничного сотрудничества является формой межрегионального взаимодействия и регионализации.

Приграничное сотрудничество осуществляется в приграничном регионе. Приграничный регион - это территория государства, расположенная вдоль его границы.

Приграничные территории - это территории, непосредственно прилегающие к государственной границе, испытывающие на себе наибольшее влияние границы и соседней страны и обладающие особым, дополнительным потенциалом развития и международного сотрудничества, «специфическим потенциалом приграничья».

Глобальные и региональные трансформации выявили особую роль приграничных территорий в развитии государств. Это связано с тем, что границы в современном мире перестали рассматриваться как барьеры, что превратило пограничье в контактную зону, в которой активно идет взаимодействие народов и наций, их культур и экономик. Межгосударственные границы стали проницаемыми (проницаемость пространства - это возможность осуществления социально-экономического и межкультурного сотрудничества).

Приграничное сотрудничество - это согласованные действия сопредельных 
регионов государств, направленные на укрепление отношений между соседними регионами, находящимися под юрисдикцией разных государств.

Приграничное сотрудничество осуществляется на основе международных соглашений и охватывает те области, которые находятся в компетенции заинтересованных сообществ и властей.

Основной целью приграничного сотрудничества является налаживание связей между приграничными территориями, поиск совместных решений схожих проблем.

Изучая приграничное сотрудничество, важно определить условия, в которых оно осуществляется, выяснить, что способствует приграничному сотрудничеству, а что ему мешает.

\section{Список литературы}

Бильчак М.В. 2014. Приграничное сотрудничество в свете современных интеграционных процессов. Доступ: https://elibrary.ru/item.asp?id=21884016

Дубровина О.Ю. 2012. Региональное измерение внешней политики Российской Федерации. Новосибирск. Изд-во НГТУ. 192 с.

Дубровина О.Ю., Плотникова О.В. 2016. Межлдународные связи регионов государств: характеристика и особенности. М.: Норма; ИНФРА-М. 192 с.

Кучинская Т.Н. 2011. Трансграничный регион как форма социокультурного пространства: в поисках когнитивной модели исследования. - Современные проблемы науки и образования. № 6. Доступ: http://science-education.ru/ru/article/ view?id=5045

Трансграничный регион: понятие, сущность форма: монография. 2010. Владивосток: Дальнаука. 275 с.

Шаповалов Д.И., Кузьмина В.М. 2015. Геополитический фактор в приграничном сотрудничестве: сборник статей. М. Доступ: https://elibrary.ru/item. asp?id=25508661

Wiles P.J.D. 1968. The Political Economy of International Integration. - Communist International Economics. N.Y.; Washington: Frederick A. Praeger.

\section{CROSS-BORDER COOPERATION AS A FORM OF INTERREGIONAL INTERACTION AND REGIONALIZATION}

\footnotetext{
Abstract. The article views cross-border cooperation as a form of interregional interaction and regionalization. The main attention is paid to the basic concepts, the specific potential of the borderland, and the special role of the border areas in the development of states. The author analyzes the transboundary phenomenon, inextricably linked with the changing functions of the boundary. The article shows that transborderity is possible only if there is a permeability of space.

The article examines the legal framework, the main goals and tasks of cross-border cooperation, as well as the most important geopolitical factors that have a significant impact on cross-border relations.

Keywords: globalization, regionalization, regions of states, international relations of regions of states, cross-border cooperation, transboundary cooperation, border area, boundary, frontier, transborderity
} 